\title{
Liver transplantation for acute-on-chronic liver failure
}

\author{
Albert C. Chan $\cdot$ Sheung Tat Fan $\cdot$ Chung Mau Lo $\cdot$ \\ Chi Leung Liu - See Ching Chan · Kelvin K. Ng • \\ Boon Hun Yong · Alexander Chiu · Banny K. Lam
}

Received: 23 April 2009/Revised: 23 July 2009/Accepted: 3 August 2009/Published online: 13 August 2009

(C) The Author(s) 2009. This article is published with open access at Springerlink.com

\begin{abstract}
Purpose To evaluate the outcome of liver transplantation for acute-on-chronic liver failure.

Patients and methods From November 1991 to December 2007, 517 patients underwent liver transplantation at Queen Mary Hospital, Hong Kong. Among them, 149 had acute-on-chronic liver failure as defined in the recent Asian Pacific Association for the Study of Liver Consensus Meeting. Their clinical data were reviewed and their survival outcomes were compared with those of patients who underwent liver transplantation for fulminant hepatic failure and for cirrhosis only in the same period.

Results The patients with acute-on-chronic liver failure included 50 patients having acute exacerbation of chronic hepatitis B and 99 cirrhotic patients with acute deterioration. Their median model for end-stage liver disease scores were 35 and 37, respectively. Preoperative infection (35\%), hepatorenal syndrome $(38 \%)$, and respiratory failure (28.8\%) were common. One hundred and three patients received living donor liver grafts and 46 patients received deceased donor liver grafts. The hospital mortality rate was $4.7 \%$. The 5-year survival rates were $93.2 \%$ for patients with
\end{abstract}

A. C. Chan · S. T. Fan $(\bowtie) \cdot$ C. M. Lo .

C. L. Liu - S. C. Chan - K. K. Ng - B. K. Lam

Department of Surgery, Queen Mary Hospital, The University

of Hong Kong, 102 Pok Fu Lam Road, Hong Kong, China

e-mail: stfan@hku.hk

B. H. Yong

Department of Anesthesiology, Queen Mary Hospital,

The University of Hong Kong, 102 Pok Fu Lam Road,

Hong Kong, China

A. Chiu

Adult Intensive Care Unit, Queen Mary Hospital,

102 Pok Fu Lam Road, Hong Kong, China acute exacerbation of chronic hepatitis B and $90.5 \%$ for cirrhotic patients with acute deterioration. The results were similar to those of the patients with fulminant hepatic failure $(n=37)$ and the patients having cirrhosis only $(n=301)$. Conclusions Liver transplantation for acute-on-chronic liver failure is life-saving, and the survival rates it attains are similar to those attained by transplantation for other liver conditions.

Keywords Acute-on-chronic liver failure . Liver transplantation $\cdot$ Living donor

\section{Introduction}

Acute-on-chronic liver failure had been an ill-defined condition until the recent Asian Pacific Association for the Study of the Liver Consensus Meeting, which defined it as "acute hepatic insult manifesting as jaundice (serum bilirubin $>5 \mathrm{mg} / \mathrm{dl}$ ) and coagulopathy (international normalized ratio $>1.5$ ), complicated within 4 weeks by ascites and/or encephalopathy in a patient with previously diagnosed or undiagnosed chronic liver disease" [1]. The prognosis is dismal when such patients develop multiorgan failure. Liver transplantation is the only curative option that can salvage them. However, data of liver transplantation for patients with acute-on-chronic liver failure are scarce. In this article, we report the outcome of our patients with such condition as defined in the consensus statement.

\section{Patients and methods}

From November 1991 to December 2007, 517 adult patients ( $\geq 17$ years old) underwent liver transplantation at 
Queen Mary Hospital, The University of Hong Kong. All of the liver explants were examined histologically. On the basis of the explant pathology reports, the patients, other than those with polycystic liver $(n=5)$, metabolic disease $(n=7)$, or retransplantation for liver graft non-function $(n=18)$, were categorized into four groups according to their conditions: group 1, patients with fulminant hepatic failure $(n=37)$; group 2 , patients with acute exacerbation of chronic hepatitis $\mathrm{B}(n=50)$; group 3 , cirrhotic patients with acute deterioration $(n=99)$; and group 4 , patients with cirrhosis only $(n=301)$. Massive or submassive hepatocyte necrosis was a prominent feature in the first two conditions. Differentiating fulminant hepatic failure from acute exacerbation of chronic hepatitis $\mathrm{B}$ was based on findings of fibrous bands and ductular proliferation in the latter condition. Cirrhosis was diagnosed on the basis of typical findings of nodules enveloped by fibrous septae. Differentiation between cirrhosis with acute deterioration and cirrhosis only was based on the presence of hepatocyte necrosis and features of acute hepatitis in the former condition. Patients in groups 2 and 3 were those with acute-onchronic liver failure and the focus of this study.

Clinical records of these four groups of patients were reviewed with the aim to ascertain that their clinical presentations did fulfill the definition of acute-on-chronic liver failure as described in the Asian Pacific Association for the Study of the Liver Consensus Meeting. Presence of hyperbilirubinemia and coagulopathy was confirmed by laboratory tests. Presence of ascites was documented by imaging studies and/or laparotomy. Hepatic encephalopathy was documented when there was disturbance in central nervous system function and the severity was graded from 1 to 4 according to the system devised by Conn and Bircha [2].

Patients in groups 1,2 , and 3 all presented clinical features of acute liver failure. Once their clinical status fulfilled the King's College Hospital criteria [3] and contraindications to liver transplantation were ruled out, the family was informed of the need for liver transplantation and the options of deceased donor liver transplantation (DDLT) and living donor liver transplantation (LDLT). While waiting for a liver graft, supportive treatment was continued. Lamivudine was given to patients with hepatitis B immediately if they had not been on nucleoside analogue. Patients with suspected infection were prescribed with broad-spectrum antibiotics after appropriate cultures had been performed. Only patients with positive bacterial or fungal culture in blood, urine, sputum, bronchoalveolar lavage fluid, or ascites were considered to have infection before transplantation. Presence of infection was not considered a contraindication to liver transplantation. If the condition of the patient was not critical, infection was treated with potent antibiotic before transplantation.
Otherwise, heavy doses of broad-spectrum antibiotic were administered perioperatively. Patients with oliguria or rapidly deteriorating renal function received hemodialysis or continuous venovenous hemofiltration. Thirteen patients received molecular adsorbents recirculating system treatment as well [4]. Endotracheal intubation and mechanical ventilation were not routinely performed unless the patient was comatose and control of airway was considered necessary. Intracranial pressure was monitored in the first few patients, but the monitoring was not done in the subsequent patients because serious complications related to insertion of intracranial pressure monitoring device were encountered. Instead, these patients were monitored by their neurological signs, and workup for the recipients and living donors (if available) was proceeded quickly to allow the patients to receive transplantation in time [5]. Computed tomography of the brain was routinely performed in all patients with impaired conscious state to rule out severe brain edema and intracranial bleeding, which were contraindications to liver transplantation.

Liver transplantation was performed with deceased donor or living donor livers by the technique previously described [6]. All deceased donor grafts were whole grafts except 6 , which were right trisegment grafts derived from splitting of livers. All, except 2, living donor grafts contained the middle hepatic vein. The living donor grafts were from right livers $(n=284)$, left livers $(n=17)$, or domino livers $(n=3)$. Venovenous bypass was used intraoperatively in the first 115 patients, but it was not used thereafter because the procedure was found not beneficial [7]. Intraoperative hemodialysis was performed in seven patients because of fluid overload, anuria, or difficulty maintaining a stable hemodynamic state and acid-base balance.

After operation, the patients were routinely maintained on mechanical ventilation until spontaneous breathing effort was evident and hemodynamic stability had been achieved. Renal support therapy was rendered when the patients had oliguria, fluid overload, or increasing serum levels of urea and creatinine.

The immunosuppressive protocol included steroid and FK506 in the initial period of the study for up to patient no. 216 in our series, and thereafter a combination of FK506, steroid, mycophenolate mofetil, and IL-2 receptor antagonist was used [8]. In the immediate postoperative period, FK506 was prescribed only when renal function had improved and adequate urine output was shown. After about 3 months, monotherapy with FK506 was maintained. Patients with hepatitis B continued to receive lifelong lamivudine. Adefovir was added when YMDD mutant was detected. Hepatitis B immunoglobulin was not given. Patients with hepatitis $\mathrm{C}$ were not given any antiviral treatment unless their liver graft showed evidence of recurrent infection. 
In this study, possible causes of acute deterioration of liver function and types of hepatic insults were documented prospectively. Variceal bleeding was considered a manifestation of elevated portal pressure but not a hepatic insult leading to the onset of acute-on-chronic liver failure. Hepatorenal syndrome (type 1) was diagnosed by urine sodium concentration of less than $10 \mathrm{mmol} / \mathrm{l}$ in the absence of ultrasonographic evidence of obstructive uropathy or parenchymal disease and lack of improvement in renal function after plasma volume expansion [9]. The severity of illness before liver transplantation was reflected by the model for end-stage liver disease (MELD) score [10]. Hospital mortality was defined as death within the same hospital admission for liver transplantation. All patients were followed up regularly in the outpatient clinic by the same team of surgeons. There was no default of follow-up. The last census date for this study was August 31, 2008. The overall patient and graft survival rates (all-cause mortalities as an end point) were estimated by the life-table method and compared between groups by the log-rank test. Discrete variables were compared by the $\chi^{2}$ test, and continuous variables were compared by the Mann-Whitney $U$ test. Stepwise logistic regression analysis was used to define factors related to hospital mortality. Multivariate analysis of factors of patient survival was performed with the Cox proportional hazards model. All statistical analyses were performed by SPSS, Version 12.0, for Windows (SPSS Inc., Chicago, IL). A value $P<0.05$ was considered statistically significant.

\section{Results}

\section{Preoperative data}

Male patients predominated in the two groups of patients with acute-on-chronic liver failure (Table 1). For patients with cirrhosis and acute deterioration, the median age was similar to that of the patients with cirrhosis only, and they were older than the patients with acute exacerbation of chronic hepatitis B and those with fulminant hepatic failure. Reactivation of hepatitis B was the cause of deterioration in all of the patients in group 2. Factors that induced the viral reactivation were largely unknown, but steroid and herbal medicine might have been responsible for $18(36 \%)$ patients (Table 2). Drugs were also a possible cause of acute deterioration in $14(14 \%)$ patients with cirrhosis (group 3). Other factors included Wilson disease and superimposed hepatitis E.

About $60 \%$ of the patients with acute-on-chronic liver failure were intensive care unit bound before liver transplantation (Table 1). The incidence was less than that of the patients with fulminant hepatic failure (versus group 2,
$P=0.034$; versus group $3, P=0.006)$. Fifty-four percent of the patients with acute exacerbation of chronic hepatitis $\mathrm{B}$ and $36 \%$ of the cirrhotic patients with acute deterioration lapsed into stage 3 or 4 coma before operation. The incidence was lower for cirrhotic patients with acute deterioration than that of the patients with fulminant hepatic failure $(P=0.001)$. The median MELD scores of the patients with acute exacerbation of chronic hepatitis $B$ and cirrhotic patients with acute deterioration were 37 and 35 , respectively. The values were similar to those of the patients with fulminant hepatic failure and were definitely higher than those of the patients with cirrhosis only (Table 1).

Infection was identified before liver transplantation in $32 \%$ of the patients with acute exacerbation of chronic hepatitis B and in $36.4 \%$ of the cirrhotic patients with acute deterioration (Tables 1 and 3). The incidence was higher than that of patients with fulminant hepatic failure (versus group 2, $P=0.131$; versus group $3, P=0.038$ ) and that of patients with cirrhosis only (versus group $2, P<0.001$; versus group $3, P<0.001)$. Twenty-two (14.8\%) patients having acute-on-chronic liver failure had positive blood culture results (Tables 1 and 3). Hepatorenal syndrome was diagnosed in $16(32 \%)$ patients with acute exacerbation of chronic hepatitis B and in $41(41.4 \%)$ cirrhotic patients with acute deterioration. The incidence, though higher, was not significantly higher than that of the patients with fulminant hepatic failure $(27 \%)$ (versus group $2, P=0.39$; versus group $3, P=0.088)$. Six (16\%), eight $(16 \%), 20$ (20\%), and 0 patients in the four groups, respectively, required preoperative hemodialysis. Seventeen (34\%) patients with acute exacerbation of chronic hepatitis B and $26(26 \%)$ cirrhotic patients with acute deterioration required mechanical ventilation. The incidence was lower than that of the patients with fulminant hepatic failure (versus group 2, $P=0.049$; versus group $3, P=0.003$ ).

\section{Intraoperative data}

Three hundred four (62.4\%) patients underwent LDLT and $183(37.6 \%)$ patients received DDLT. The proportions of LDLT in the four groups were 83, 78, 65.7, and $56.4 \%$, respectively (Table 4 ). There was no statistical difference in the weight of the grafts they received, irrespective of graft types. Cirrhotic patients with acute deterioration had the highest blood transfusion requirement (versus group $1, P=0.091$; versus group 2, $P=0.021$; versus group $4, P<0.001)$. However, seven $(18.9 \%)$, five $(10 \%)$, three $(3 \%)$, and $66(21.9 \%)$ patients in groups 1, 2, 3, and 4, respectively, did not require exogenous blood transfusion. Seven patients required intraoperative hemodialysis. Five of them were cirrhotic patients with acute deterioration. 
Table 1 Preoperative data

\begin{tabular}{|c|c|c|c|c|}
\hline & $\begin{array}{l}\text { Fulminant hepatic } \\
\text { failure }(n=37)\end{array}$ & $\begin{array}{l}\text { Acute exacerbation of chronic } \\
\text { hepatitis } \mathrm{B}(n=50)\end{array}$ & $\begin{array}{l}\text { Cirrhosis with acute } \\
\text { deterioration }(n=99)\end{array}$ & $\begin{array}{l}\text { Cirrhosis } \\
(n=301)\end{array}$ \\
\hline Male: Female & $13: 24$ & $39: 11$ & $85: 14$ & $224: 77$ \\
\hline Age, median (range) & $34(19-60)$ & $44(17-63)$ & $49(17-66)$ & $50(17-68)$ \\
\hline \multicolumn{5}{|l|}{ Pre-transplant status } \\
\hline Intensive care unit-bound & $31(83.8 \%)$ & $32(64 \%)$ & $59(59.6 \%)$ & $12(4 \%)$ \\
\hline Hospital-bound & $6(16.2 \%)$ & $17(34 \%)$ & $40(40.4 \%)$ & $67(22.2 \%)$ \\
\hline From home & 0 & $1(2 \%)$ & 0 & $222(73.8 \%)$ \\
\hline MELD score, median (range) & $37(27-52)$ & $37(28-52)$ & $35(19-59)$ & $17(6-41)$ \\
\hline $\begin{array}{l}\text { Serum bilirubin }(\mu \mathrm{mol} / \mathrm{l}) \text {, } \\
\text { median (range) }\end{array}$ & $549(91-879)$ & $570(321-957)$ & $585(86-1,209)$ & $57(9-957)$ \\
\hline $\begin{array}{l}\text { Serum ALT (IU/l), } \\
\text { median (range) }\end{array}$ & $502(33-7,150)$ & $331(34-2,389)$ & $75(14-4,020)$ & $43(7-270)$ \\
\hline $\begin{array}{l}\text { Serum AST (IU/l), } \\
\text { median (range) }\end{array}$ & $281(77-10,000)$ & $178(46-2,056)$ & $117(33-5,590)$ & $64(21-300)$ \\
\hline $\begin{array}{l}\text { Serum urea }(\mathrm{mmol} / \mathrm{l}) \\
\text { median (range) }\end{array}$ & $2.4(0.2-36)$ & $4.25(0.4-32)$ & $6.8(1.7-51.9)$ & $4.9(1.6-36.6)$ \\
\hline $\begin{array}{l}\text { Serum creatinine }(\mu \mathrm{mol} / \mathrm{l}) \text {, } \\
\text { median (range) }\end{array}$ & $82(36-658)$ & $103(43-563)$ & $115(38-971)$ & $86(39-896)$ \\
\hline $\begin{array}{l}\text { White cell count }\left(\times 10^{9} / 1\right) \text {, } \\
\text { median (range) }\end{array}$ & $9.35(3.3-49.4)$ & $9.35(1.8-25.5)$ & $7.85(1.7-30.2)$ & $4.2(0.7-17.9)$ \\
\hline $\begin{array}{l}\text { Platelet count }\left(\times 10^{9} / 1\right) \text {, } \\
\text { median (range) }\end{array}$ & $129(44-671)$ & $127(45-352)$ & $62(17-360)$ & $57(11-537)$ \\
\hline INR, median (range) & $4.4(1.8-8.4)$ & $3.5(1.8-5.7)$ & $2.8(1.6-10.0)$ & $1.5(1.0-4.4)$ \\
\hline \multicolumn{5}{|l|}{ Hepatic encephalopathy } \\
\hline Grade 0 & $2^{\mathrm{a}}$ & 12 & 33 & 292 \\
\hline Grade 1 & 4 & 5 & 11 & 4 \\
\hline Grade 2 & 6 & 6 & 19 & 1 \\
\hline Grade 3 & $11(29.7 \%)$ & $15(30 \%)$ & $14(14.1 \%)$ & 2 \\
\hline Grade 4 & $14(37.8 \%)$ & $12(24 \%)$ & $22(22 \%)$ & 2 \\
\hline Preoperative infection & $7(18.9 \%)$ & $16(32 \%)$ & $36(36.4 \%)$ & $6(2.0 \%)$ \\
\hline Respiratory tract & 2 & 6 & 21 & 2 \\
\hline Urinary tract & 4 & 4 & 11 & 1 \\
\hline Ascites & 0 & 1 & 0 & 3 \\
\hline Blood & 1 & 7 & 15 & 1 \\
\hline Other sites & 0 & 0 & 8 & 3 \\
\hline Hepatorenal syndrome & $10(27 \%)$ & $16(32 \%)$ & $41(41.4 \%)$ & $2(0.7 \%)$ \\
\hline Preoperative hemodialysis & $6(16.2 \%)$ & $8(16 \%)$ & $20(20.2 \%)$ & $0(0 \%)$ \\
\hline Mechanical ventilation support & $20(54.1 \%)$ & $17(34 \%)$ & $26(26.3 \%)$ & $2(0.7 \%)$ \\
\hline
\end{tabular}

a Stage of hepatic encephalopathy was not clearly documented

MELD Model for end-stage liver disease, ALT alanine aminotransferase, AST aspartate aminotransferase, INR international normalized ratio

\section{Pathological data}

Hepatocellular carcinoma (HCC) was found in the liver explants of $11(11.1 \%)$ cirrhotic patients with acute deterioration and 105 (34\%) patients having cirrhosis only (Table 4) but not in any of the explants from patients with acute exacerbation of chronic hepatitis B. The finding of HCC was incidental in five $(45.5 \%)$ cirrhotic patients with acute deterioration because thorough imaging of the liver had not been carried out before the emergency transplantation. However, almost $90 \%$ of the HCCs in this group were in early stage. Etiologies of cirrhosis (according to pathology of the explants) were similar in groups 3 and 4 (Table 5). The causes for fulminant hepatic failure are as follows: acute hepatitis B in 11 patients, drug intoxication in 12 patients, and unknown in 13 patients. 
Table 2 Possible factors leading to acute exacerbation of hepatitis B and acute deterioration of cirrhotic patients

\begin{tabular}{lll}
\hline & $\begin{array}{l}\text { Acute exacerbation of } \\
\text { hepatitis B }(n=50)\end{array}$ & $\begin{array}{l}\text { Cirrhosis with acute } \\
\text { deterioration }(n=99)\end{array}$ \\
\hline Unknown & 30 & 71 \\
Herbal medicine & 15 & 11 \\
Steroid & 3 & 2 \\
Interleukin & 1 & 0 \\
Cyclosporine A & 1 & 0 \\
$\quad$ withdrawal & & \\
Hepatitis E infection & 0 & 1 \\
YMDD mutant & 0 & 3 \\
Withdrawal of & 0 & 1 \\
nucleoside & & \\
analogue & & 3 \\
$\begin{array}{l}\text { Wilson disease } \\
\text { Unknown hepatitis C } \\
\text { virus }\end{array}$ & 0 & 1 \\
$\begin{array}{l}\text { Post-hepatectomy } \\
\text { portal vein } \\
\text { thrombosis }\end{array}$ & 0 & \\
$\begin{array}{l}\text { Anti-tuberculosis } \\
\text { drugs }\end{array}$ & 0 & \\
$\begin{array}{l}\text { Unknown Wilson } \\
\text { disease }\end{array}$ & 0 & \\
\hline
\end{tabular}

Postoperative data

Early complications ( $<30$ days) occurred in $62 \%$ of the patients with acute exacerbation of chronic hepatitis $B$ and in $70.7 \%$ of the cirrhotic patients with acute deterioration
(Table 6). The incidence in the latter group was higher than that of the patients with cirrhosis only $(P<0.001)$. However, the incidence of reoperations for complications was similar among the four groups, regardless of whether the initial operations were LDLT or DDLT. Patients with acute-on-chronic liver failure had a higher need for hemodialysis after operation. Their durations of intensive care unit stay were also longer than those of the patients having cirrhosis only (versus group 2, $P=0.014$; versus group $3, P<0.001)$. However, among patients in groups 1 , 2 , and 3 , patients with acute exacerbation of chronic hepatitis B had the shortest hospital stay. Their recovery of liver and renal functions was rapid and similar to that of the patients with cirrhosis (Fig. 1). Patients with acute-onchronic liver failure had significantly higher serum creatinine levels on postoperative days 1,2 , and 3 .

\section{Survival data}

The hospital mortality rates were 4.0 and $5.1 \%$ for patients with acute exacerbation of chronic hepatitis B and cirrhotic patients with acute deterioration, respectively (Table 6). The hospital mortality rate of all patients with acute-onchronic liver failure was $4.7 \%$, which was not significantly higher than that of patients with fulminant hepatic failure $(2.7 \%)$ and that of patients with cirrhosis only (7\%). Five $(71.4 \%)$ of the seven patients who needed intraoperative hemodialysis died. Causes of hospital mortality are listed in Table 7. Multivariate analyses of preoperative parameters (age, pretransplant status, MELD score, platelet count,

Table 3 Bacteriology of cultures of fluid according to patient groups and sites of origin

\begin{tabular}{|c|c|c|c|c|c|c|c|}
\hline & \multicolumn{6}{|c|}{ Bacteria } & \multirow{2}{*}{$\begin{array}{l}\text { Fungus } \\
\text { Candida }\end{array}$} \\
\hline & MRSA & MSSA & E. coli & Klebsiella & Pseudomonas & Others & \\
\hline \multicolumn{8}{|l|}{ Patient group } \\
\hline Fulminant hepatic failure & 1 & 0 & 2 & 2 & 0 & 2 & 2 \\
\hline Acute exacerbation of chronic hepatitis B & 0 & 1 & 2 & 3 & 1 & 11 & 3 \\
\hline Cirrhosis with acute deterioration & 9 & 10 & 8 & 5 & 3 & 19 & 14 \\
\hline Cirrhosis & 1 & 0 & 2 & 0 & 0 & 2 & 2 \\
\hline \multicolumn{8}{|l|}{ Site of origin } \\
\hline Respiratory tract & 4 & 6 & 1 & 5 & 3 & 18 & 14 \\
\hline Urinary tract & 2 & 0 & 8 & 4 & 0 & 9 & 7 \\
\hline Ascites & 2 & 0 & 1 & 0 & 1 & 0 & 1 \\
\hline Blood & 3 & 3 & 8 & 2 & 1 & 7 & 1 \\
\hline Other sites & 1 & 2 & 2 & 0 & 1 & 1 & 5 \\
\hline
\end{tabular}

MRSA Methicillin-resistant staphylococcus aureus, MSSA Methicillin-sensitive staphylococcus aureus

Others: Coagulase negative staphylococcus $(n=1)$, Streptococci vividans $(n=1), \alpha$-hemolytic streptococcus $(n=16)$, Enterococcus fecalis $(n=2)$, Enterococcus species $(n=10)$, Diphtheroid bacilli $(n=1)$, Enterobacter agglomeraus $(n=1)$, Proteus sp. $(n=1)$, Moraxella species $(n=1)$, Propionibacterium acnes $(n=1)$, Acinetobacter baumannii $(n=6)$, Morganella morganii $(n=1)$, Nisseria species $(n=2)$, Stomatococcus mucilaginosus $(n=2)$, Clostridium difficile $(n=1)$, Hemophilius parahemolyticus $(n=1)$, Mycobacterium tuberculosis $(n=1)$, Acinetobacter species $(n=1)$, and Aeromonas hydrophilia $(n=1)$ 
Table 4 Intraoperative data

\begin{tabular}{|c|c|c|c|c|}
\hline & $\begin{array}{l}\text { Fulminant hepatic } \\
\text { failure }(n=37)\end{array}$ & $\begin{array}{l}\text { Acute exacerbation of chronic } \\
\text { hepatitis } \mathrm{B}(n=50)\end{array}$ & $\begin{array}{l}\text { Cirrhosis with acute } \\
\text { deterioration }(n=99)\end{array}$ & $\begin{array}{l}\text { Cirrhosis } \\
(n=301)\end{array}$ \\
\hline LDLT: DDLT & $31: 6$ & $38: 12$ & $65: 34$ & 170:131 \\
\hline Graft weight/ESLV (\%) & $53.6(27.4-117.1)$ & $52.7(36.9-135.5)$ & $54.0(28.4-140.8)$ & $59.3(27.3-186.8)$ \\
\hline $\begin{array}{l}\text { Graft weight/recipient body } \\
\text { weight }(\%)\end{array}$ & $1.05(0.53-1.98)$ & $0.99(0.64-2.65)$ & $1.01(0.49-3.07)$ & $1.14(0.49-4.29)$ \\
\hline $\begin{array}{l}\text { Living donor graft weight/ESLV } \\
(\%)\end{array}$ & $52.2(27.4-89.4)$ & $49.7(36.9-86.9)$ & $46.8(28.4-68.9)$ & $49.0(27.3-79.5)$ \\
\hline $\begin{array}{l}\text { Living donor graft weight/ } \\
\text { recipient body weight }(\%)\end{array}$ & $0.95(0.53-1.92)$ & $0.90(0.64-1.95)$ & $0.87(0.49-1.31)$ & $0.91(0.49-1.51)$ \\
\hline $\begin{array}{l}\text { Blood transfusion units, median } \\
\text { (range) }\end{array}$ & $7(0-15)$ & $4.5(0-30)$ & $7(0-58)$ & $5(0-108)$ \\
\hline $\begin{array}{l}\text { No. of patients without blood } \\
\text { transfusion }\end{array}$ & $7(18.9 \%)$ & $5(10 \%)$ & $3(3 \%)$ & $66(21.9 \%)$ \\
\hline $\begin{array}{l}\text { FFP transfusion units, median } \\
\text { (range) }\end{array}$ & $12(2-26)$ & $13(3-37)$ & $13(5-48)$ & $8(0-66)$ \\
\hline $\begin{array}{l}\text { Platelet transfusion units, median } \\
\text { (range) }\end{array}$ & $6(0-20)$ & $5(0-32)$ & $12(0-53)$ & $10(0-51)$ \\
\hline Intraoperative hemodialysis & $1(2.7 \%)$ & $1(2.0 \%)$ & $5(5.1 \%)$ & $0(0 \%)$ \\
\hline $\begin{array}{l}\text { Concomitant hepatocellular } \\
\text { carcinoma }\end{array}$ & $0(0 \%)$ & $0(0 \%)$ & $11(11.1 \%)$ & $105(34.9 \%)$ \\
\hline $\begin{array}{l}\text { Incidental hepatocellular } \\
\text { carcinoma }\end{array}$ & 0 & 0 & $5(45.5 \%)$ & $6(5.7 \%)$ \\
\hline TNM stage I & 0 & 0 & $5(45.5 \%)$ & $41(39 \%)$ \\
\hline TNM stage II & 0 & 0 & $5(45.5 \%)$ & $51(48.6 \%)$ \\
\hline TNM stage III & 0 & 0 & $1(9.1 \%)$ & $12(11.4 \%)$ \\
\hline TNM stage IV & 0 & 0 & $0(0 \%)$ & $1(1.0 \%)$ \\
\hline
\end{tabular}

$L D L T$ living donor liver transplantation, $D D L T$ deceased donor liver transplantation, $E S L V$ estimated standard liver volume, $F F P$ fresh frozen plasma, TNM tumor-node-metastasis

Table 5 Etiologies of cirrhosis based on explant pathology

\begin{tabular}{|c|c|c|}
\hline & $\begin{array}{l}\text { Cirrhosis with acute } \\
\text { deterioration }(n=99)\end{array}$ & $\begin{array}{l}\text { Cirrhosis } \\
(n=301)\end{array}$ \\
\hline Hepatitis B & $85(85.9 \%)$ & $222(73.8 \%)$ \\
\hline Hepatitis C & $2(2 \%)$ & $27(9 \%)$ \\
\hline Hepatitis B and C & $1(1 \%)$ & $2(0.7 \%)$ \\
\hline Wilson disease & $7(7.1 \%)$ & $4(1.3 \%)$ \\
\hline $\begin{array}{l}\text { Autoimmune } \\
\text { hepatitis }\end{array}$ & $1(1 \%)$ & $3(1 \%)$ \\
\hline Alcoholic cirrhosis & $2(2 \%)$ & $14(4.7 \%)$ \\
\hline Idiopathic cirrhosis & $1((1 \%)$ & $6(2 \%)$ \\
\hline $\begin{array}{l}\text { Secondary biliary } \\
\text { cirrhosis }\end{array}$ & $0(0 \%)$ & $6(1.7 \%)$ \\
\hline $\begin{array}{l}\text { Primary biliary } \\
\text { cirrhosis }\end{array}$ & $0(0 \%)$ & $16(5.3 \%)$ \\
\hline $\begin{array}{l}\text { Overlapping } \\
\text { syndrome }\end{array}$ & $0(0 \%)$ & $1(0.3 \%)$ \\
\hline
\end{tabular}

presence of hepatic encephalopathy, infection or hepatorenal syndrome, and need for preoperative hemodialysis or mechanical ventilatory support), intraoperative parameters
(LDLT versus DDLT, graft weight-to-estimated standard liver volume ratio, graft weight-to-recipient body weight ratio, volume of blood transfusion, volume of fresh frozen plasma transfusion, platelet concentrates, and need for intraoperative hemodialysis), and diagnosis groups showed that intraoperative blood transfusion volume was the only significant factor that could predict hospital mortality (relative risk, 1.119; 95\% confidence interval, 1.0771.163). According to discriminant analysis, blood transfusion volume of 14.51 was the cutoff level that could predict hospital mortality.

The median follow-up durations of the four groups of patients were $73.4,53.9,55.5$, and 46.9 months, respectively, and the ranges were 3.3-172.1, 0.37-149.1, 0.33149.9, and 0-179.1 months, respectively. There was no default in follow-up. The 1-year graft survival rate exceeded $90 \%$ in all four groups of patients. The estimated 5 -year survival rates of patients with acute exacerbation of chronic hepatitis B and cirrhotic patients with acute deterioration were 93.2 and $90.5 \%$, respectively (Table 6). Causes of late mortalities are listed in Table 8. According to the Cox proportional hazards model, factors leading to 
Table 6 Postoperative and survival data

\begin{tabular}{|c|c|c|c|c|}
\hline & $\begin{array}{l}\text { Fulminant hepatic } \\
\text { failure }(n=37)\end{array}$ & $\begin{array}{l}\text { Acute exacerbation of chronic } \\
\text { hepatitis } \mathrm{B}(n=50)\end{array}$ & $\begin{array}{l}\text { Cirrhosis with acute } \\
\text { deterioration }(n=99)\end{array}$ & $\begin{array}{l}\text { Cirrhosis } \\
(n=301)\end{array}$ \\
\hline $\begin{array}{l}\text { Early complications } \\
\text { ( }<30 \text { days })\end{array}$ & $26(70.3 \%)$ & $31(62 \%)$ & $70(70.7 \%)$ & $158(52.5 \%)$ \\
\hline Re-operation & $10(27 \%)$ & $8(16 \%)$ & $22(22 \%)$ & $51(16.9 \%)$ \\
\hline LDLT & $8(25.8 \%)$ & $8(21 \%)$ & $15(23 \%)$ & $24(14.1 \%)$ \\
\hline DDLT & $2(33.3 \%)$ & $0(0 \%)$ & $7(20.5 \%)$ & $27(20.6 \%)$ \\
\hline Postoperative hemodialysis & $2(5.4 \%)$ & $5(10 \%)$ & $11(11.1 \%)$ & $0(0 \%)$ \\
\hline $\begin{array}{l}\text { Intensive care unit days, } \\
\text { median (range) }\end{array}$ & $6(1-35)$ & $6(1-37)$ & $5(1-125)$ & $4(1-99)$ \\
\hline $\begin{array}{l}\text { Hospital days, median } \\
\text { (range) }\end{array}$ & $29(8-183)$ & $18(10-79)$ & $24(8-210)$ & $17(0-1,163)$ \\
\hline Hospital mortality & $1(2.7 \%)$ & $2(4.0 \%)$ & $5(5.1 \%)$ & $21(7 \%)$ \\
\hline One-year graft survival rate & $97.3 \%$ & $94 \%$ & $95 \%$ & $89.4 \%$ \\
\hline Three-year graft survival rate & $91.8 \%$ & $94 \%$ & $90.5 \%$ & $81.7 \%$ \\
\hline Five-year graft survival rate & $87.4 \%$ & $91.2 \%$ & $90.5 \%$ & $76.2 \%$ \\
\hline Re-transplantation & $3(8.1 \%)$ & $1(2 \%)$ & $0(0 \%)$ & $11(3.7 \%)$ \\
\hline $\begin{array}{l}\text { One-year overall survival } \\
\text { rate }\end{array}$ & $97.3 \%$ & $96 \%$ & $95 \%$ & $90.7 \%$ \\
\hline $\begin{array}{l}\text { Three-year overall survival } \\
\text { rate }\end{array}$ & $91.8 \%$ & $96 \%$ & $90.5 \%$ & $83.7 \%$ \\
\hline $\begin{array}{l}\text { Five-year overall survival } \\
\text { rate }\end{array}$ & $91.8 \%$ & $93.2 \%$ & $90.5 \%$ & $79.3 \%$ \\
\hline
\end{tabular}
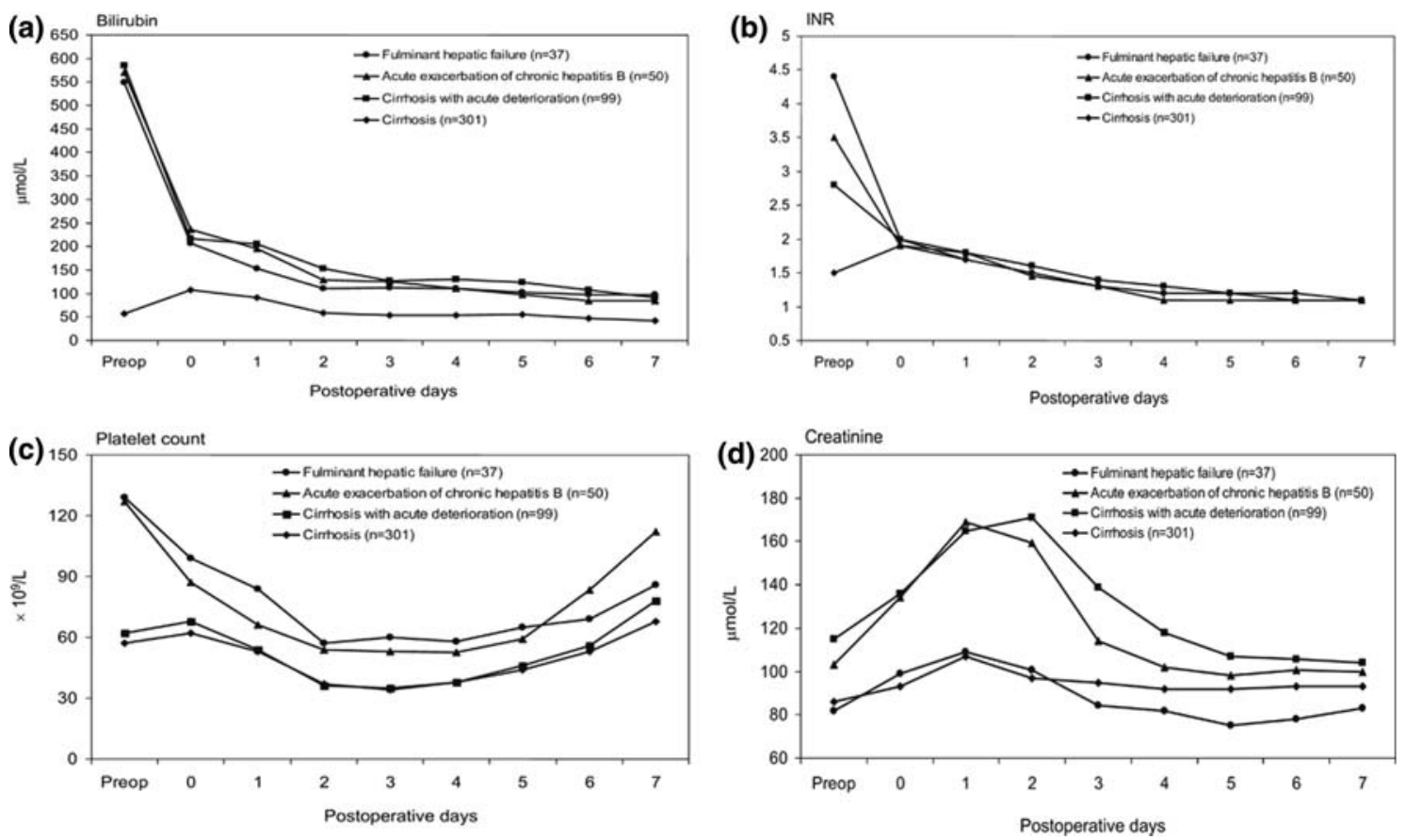

Fig. 1 Median preoperative and postoperative a serum total bilirubin levels, b international normalized ratio (INR) values, $\mathbf{c}$ platelet counts, and d creatinine levels of the four groups of patients

late mortality were MELD score (relative risk, 0.959; $95 \%$ confidence interval, 0.935-0.984) and the need for intraoperative hemodialysis (relative risk, 11.415; 95\% confidence interval, 2.471-52.765). Because the MELD score had a paradoxical effect on late mortality, a further analysis was carried out. It was identified that many HCC 
Table 7 Causes of hospital mortalities

\begin{tabular}{|c|c|c|c|c|}
\hline & $\begin{array}{l}\text { Fulminant hepatic } \\
\text { failure }(n=37)\end{array}$ & $\begin{array}{l}\text { Acute exacerbation of } \\
\text { chronic hepatitis B }(n=50)\end{array}$ & $\begin{array}{l}\text { Cirrhosis with acute } \\
\text { deterioration }(n=99)\end{array}$ & $\begin{array}{l}\text { Cirrhosis } \\
(n=301)\end{array}$ \\
\hline $\begin{array}{l}\text { Septic } \\
\text { complications }\end{array}$ & 0 & 1 & 2 & 4 \\
\hline $\begin{array}{l}\text { Cardiac } \\
\text { complications }\end{array}$ & 0 & 0 & 0 & 4 \\
\hline $\begin{array}{l}\text { Respiratory } \\
\text { complications }\end{array}$ & 0 & 0 & 0 & 1 \\
\hline Biliary leakage & 0 & 0 & 0 & 1 \\
\hline $\begin{array}{l}\text { Autoimmune } \\
\text { disorders }\end{array}$ & 1 & 0 & 0 & 1 \\
\hline $\begin{array}{r}\text { Intracranial } \\
\text { pathology }\end{array}$ & 0 & 0 & 1 & 5 \\
\hline $\begin{array}{l}\text { Multiorgan } \\
\text { failure }\end{array}$ & 0 & 0 & 1 & 1 \\
\hline $\begin{array}{l}\text { Graft } \\
\text { complications }\end{array}$ & 0 & 0 & 0 & 3 \\
\hline $\begin{array}{l}\text { Severe } \\
\text { hemorrhage }\end{array}$ & 0 & 0 & 0 & 1 \\
\hline $\begin{array}{l}\text { Intraabdominal } \\
\text { complications }\end{array}$ & 0 & 1 & 1 & 0 \\
\hline
\end{tabular}

Table 8 Causes of late mortalities

\begin{tabular}{|c|c|c|c|c|}
\hline & $\begin{array}{l}\text { Fulminant hepatic } \\
\text { failure }(n=37)\end{array}$ & $\begin{array}{l}\text { Acute exacerbation of } \\
\text { chronic hepatitis B }(n=50)\end{array}$ & $\begin{array}{l}\text { Cirrhosis with acute } \\
\text { deterioration }(n=99)\end{array}$ & $\begin{array}{l}\text { Cirrhosis } \\
(n=301)\end{array}$ \\
\hline Rejection & 1 & 0 & 0 & 2 \\
\hline $\begin{array}{l}\text { Graft } \\
\text { complications }\end{array}$ & 2 & 0 & 2 & 2 \\
\hline $\begin{array}{l}\text { Hepatitis B/C } \\
\text { infection }\end{array}$ & 0 & 0 & 0 & 3 \\
\hline Sepsis & 1 & 0 & 2 & 4 \\
\hline $\begin{array}{l}\text { Cardiac } \\
\text { complications }\end{array}$ & 0 & 0 & 0 & 1 \\
\hline $\begin{array}{l}\text { Respiratory } \\
\text { complications }\end{array}$ & 0 & 0 & 0 & 5 \\
\hline $\begin{array}{l}\text { Hematological } \\
\text { disorders }\end{array}$ & 0 & 0 & 0 & 3 \\
\hline $\begin{array}{l}\text { Gastrointestinal } \\
\text { bleeding }\end{array}$ & 0 & 0 & 0 & 3 \\
\hline $\begin{array}{l}\text { Terminal } \\
\text { malignancy }\end{array}$ & 0 & 1 & 1 & 15 \\
\hline Others & 1 & 0 & 0 & 2 \\
\hline
\end{tabular}

patients who died of tumor recurrence had low MELD scores. After excluding the HCC patients, repeated multivariate analyses showed that graft type (i.e., living donor graft) was associated with better survival (relative risk, 0.509 ; 95\% confidence interval, 0.265-0.98).

Further analysis was performed to exclude the influence of HCC on long-term survival. After excluding the HCC patients in groups 3 and 4, the difference in survival was still significant, with group 3 patients having better longterm survival rates (Fig. 2).
Fourteen patients underwent retransplantation because of primary non-function $(n=1)$, hepatic artery thrombosis $(n=2)$, portal vein thrombosis $(n=5)$, bile duct stricture $(n=1)$, unknown hepatitis $(n=2)$, recurrent hepatitis $\mathrm{B}$ $(n=2)$, and recurrent hepatitis $\mathrm{C}(n=2)$. Because the retransplantation rate was low, the overall patient survival rates were similar to the graft survival rates (Table 6). The overall survival rates of patients receiving DDLT and those having LDLT were not dissimilar in all the four groups (Fig. 3). 


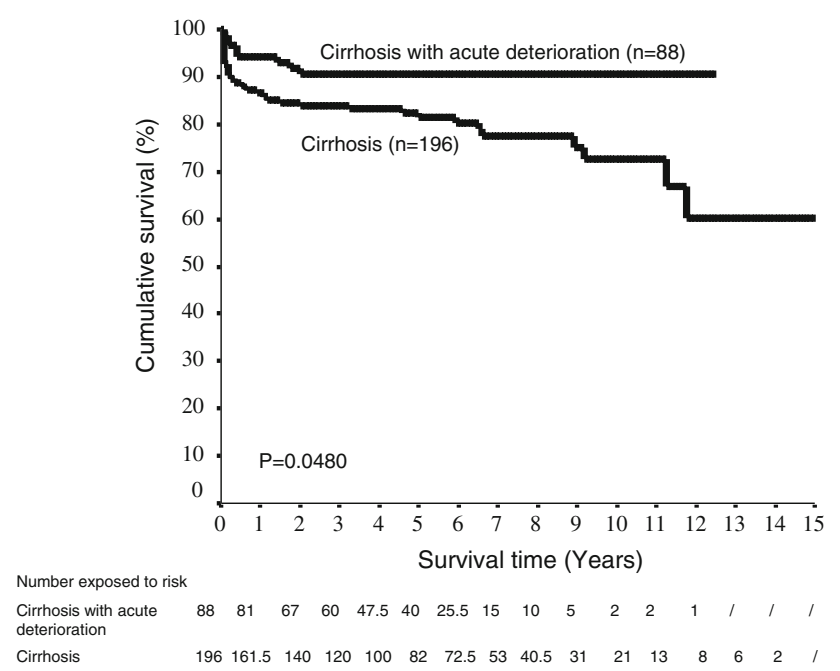

Fig. 2 Cumulative survival curves of non-hepatocellular carcinoma cirrhotic patients with and without acute deterioration
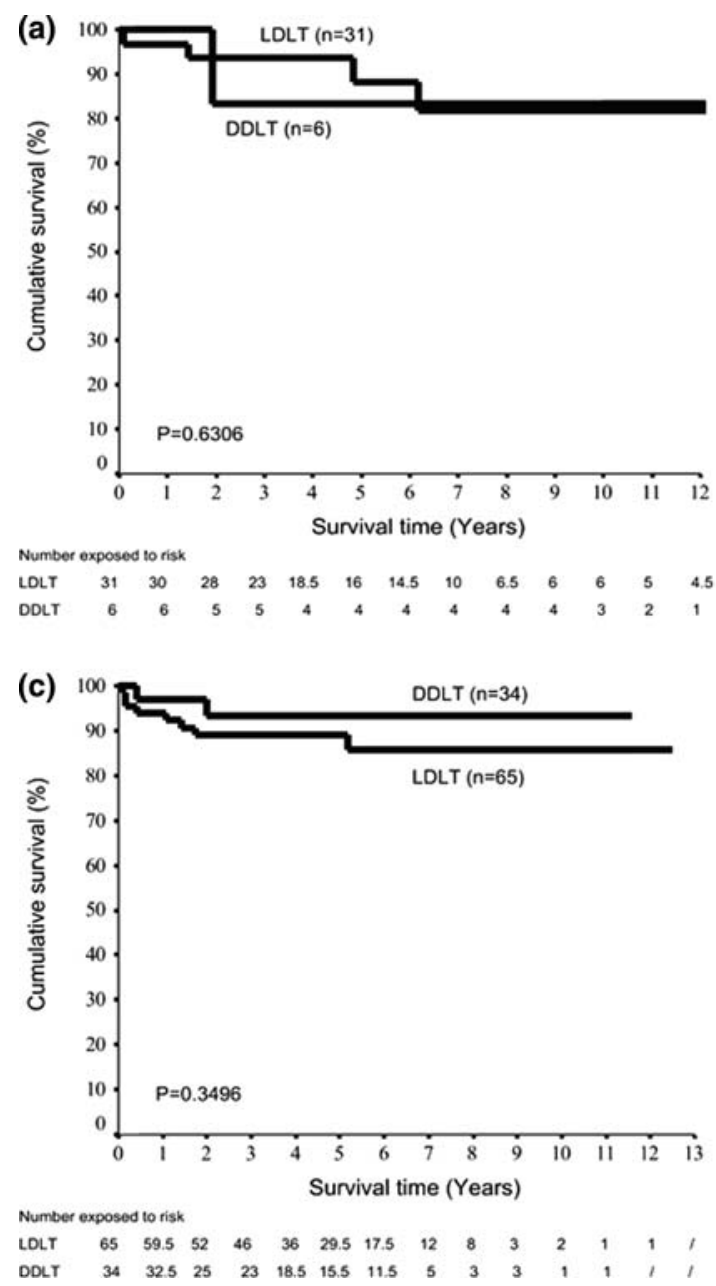

Fig. 3 Cumulative survival curves of a patients with fulminant hepatic failure, $\mathbf{b}$ patients with acute exacerbation of chronic hepatitis B, c cirrhotic patients with acute deterioration, and $\mathbf{d}$ patients with

\section{Discussion}

The study demonstrated that patients with acute-on-chronic liver failure were at high risk of dying because of a high incidence of concomitant infection (including septicemia) and renal and respiratory failure. The severity of pretransplant illness of the patients with acute-on-chronic liver failure was reflected by their high MELD scores. Such patients probably belonged to status IIA in the United Network for Organ Sharing classification of waiting list for liver transplantation. However, with timely liver transplantation, particularly with the availability of LDLT, most of them were salvaged with rapid normalization of hepatic and renal functions. Their long-term survival rates are also satisfactory. Comparing them with the patients with fulminant hepatic failure and those with cirrhosis only, all treated in the same center and period, the outcome is equally satisfactory. Compared with the scanty data from
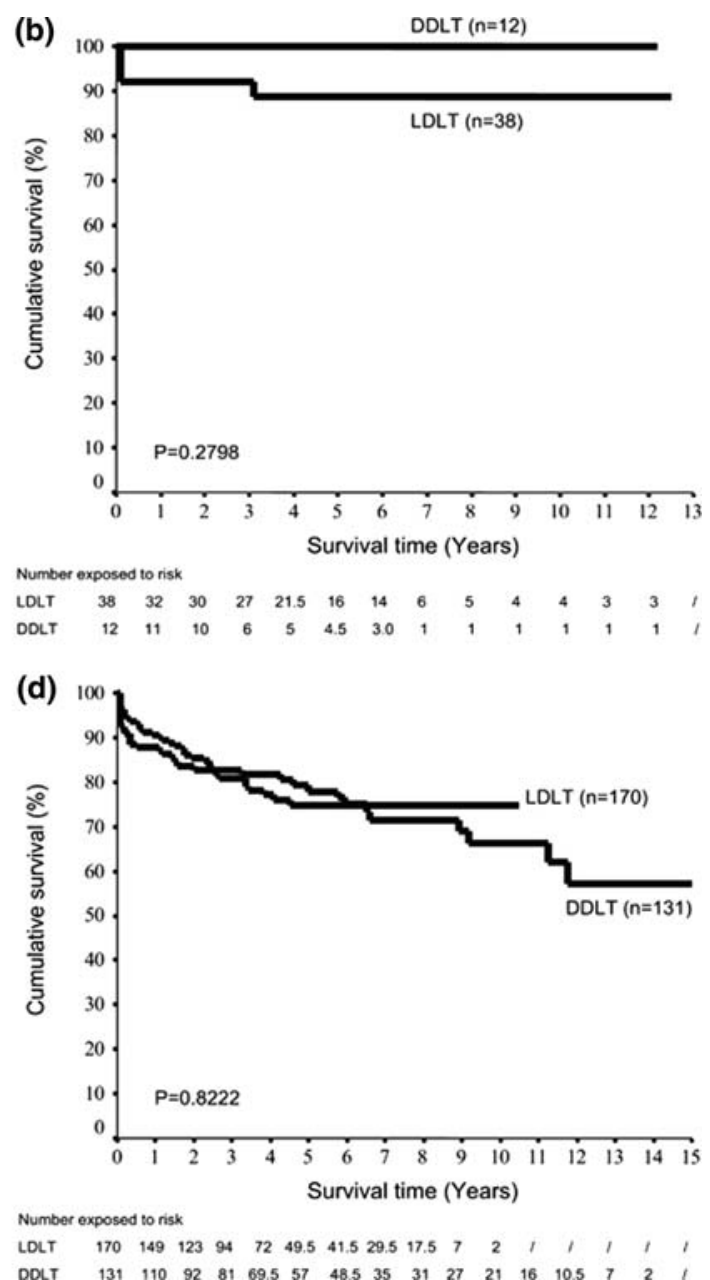

cirrhosis only. Comparison between patients who underwent deceased donor liver transplantation (DDLT) and those who underwent living donor liver transplantation (LDLT) 
the literature, the outcome of the patients reported in this study is probably superior [11-14].

The patients with acute-on-chronic liver failure had two hepatic insults: acute liver injury on top of chronic liver damage. Those with chronic hepatitis B had various degrees of liver fibrosis but preserved liver function. Their pretransplant conditions were similar to those of the patients with fulminant hepatic failure. However, because their clinical deterioration was less fulminant, the incidence of intensive care unit admission in this group was lower. Patients having established cirrhosis with superimposed acute liver injury represented the highest risk group. They might be nutritionally depleted or might have suffered ill effects of portal hypertension. In previous studies, the outcome of liver transplantation for these patients was unfavorable [11-14]. The unfavorable outcome was probably related to the timing of liver transplantation and graft quality. If liver transplantation could be carried out before irreversible multiorgan failure, and if the liver grafts were optimal in function, as shown in this series, even patients with preoperative infection and renal and respiratory failure could be salvaged. The results of our patients who underwent LDLT are favorable because nearly all our living grafts contained the middle hepatic vein, which allows uniform and complete venous drainage of the graft [15].

In our center, we offer options of both LDLT and DDLT. Supply of deceased donor liver grafts in our locality is scarce. The donor rate is about three per million population per year. Patients on the waiting list for DDLT are prioritized by MELD score. Thus, patients with acute-on-chronic liver failure are always on the top of the list and receive deceased donor grafts once they are available. Nevertheless, only a fortunate few can be supported in the intensive care unit and undergo DDLT in time. The molecular adsorbents recirculation system has been especially useful in bridging some of our patients to DDLT [16].

In this study, the 5-year overall survival rate of patients with acute-on-chronic liver failure exceeded $90 \%$. Patients with cirrhosis only had less favorable long-term survival because many of them developed HCC and died of tumor recurrence. HCC was also present in $11 \%$ of the cirrhotic patients with acute deterioration, but their long-term survival was not affected, probably because the tumors were in early stage. However, even with exclusion of HCC patients, the cirrhotic patients with acute deterioration still had significantly better survival rates than the patients with cirrhosis only. The exact reason is not known.

In conclusion, the short-term and long-term survival rates after liver transplantation for acute-on-chronic liver failure are similar to those after transplantation for other liver conditions. Timely transplantation, especially by LDLT in regions with scarcity of deceased donor livers, is the only modality that can salvage patients of acute-onchronic liver failure. However, the timing and indication for transplantation for this illness are not yet well defined. In the present study, the timing was determined according to the King's College Hospital criteria. Patients with acute exacerbation of chronic hepatitis B demonstrate many clinical features similar to those demonstrated by patients with fulminant hepatic failure, so the King's College Hospital criteria may be applicable to them. For cirrhotic patients with acute deterioration, their underlying cirrhosis status may prevent them from recovering spontaneously. For such patients, the King's College Hospital criteria may not be applicable. In fact, there exists a set of criteria established previously for acute-on-chronic liver failure [17], but it carries the deficiency that the criteria were established on a relatively small patient database. At present, a large-scale study based on data of all patients with acute-on-chronic liver failure admitted to our center is on the way. Identification of factors predicting mortality and the need for liver transplantation will allow earlier transplantation and a higher salvage rate.

Open Access This article is distributed under the terms of the Creative Commons Attribution Noncommercial License which permits any noncommercial use, distribution, and reproduction in any medium, provided the original author(s) and source are credited.

\section{References}

1. Sarin SK, Kumar A, Almeida JA, Chawla YK, Fan ST, Garg H, et al. Acute-on-chronic liver failure: consensus recommendations of the Asian Pacific Association for the Study of the liver (APASL). Hepatol Int 2009;3:269-282

2. Conn H, Bircha J. The Hepatic Encephalopathies. In Conn HB, Bircha J, editors. Hepatic Encephalopathy. Syndromes and Therapies. Bloomington, IL: Medi-Ed Press; 1994. 1-12

3. O'Grady JG, Alexander GJ, Hayllar KM, Williams R. Early indicators of prognosis in fulminant hepatic failure. Gastroenterology 1989;97:439-445

4. Chiu A, Chan LM, Fan ST. Molecular adsorbent recirculating system treatment for patients with liver failure: the Hong Kong experience. Liver Int 2006;26:695-702

5. Chan SC, Fan ST, Liu CL, Lo CM, Lam BK, Lee EW. Working up donors for high-urgency and elective adult-to-adult live donor liver transplantation. Liver Transpl 2007;13:509-515

6. Fan ST. Living donor liver transplantation. Shenzhen, China: Takungpao; 2007. Available from http://www.ldlt.hk/

7. Fan ST, Yong BH, Lo CM, Liu CL, Wong J. Right lobe living donor liver transplantation with or without venovenous bypass. Br J Surg 2003;90:48-56

8. Liu CL, Fan ST, Lo CM, Chan SC, Ng IO, Lai CL, et al. Interleukin-2 receptor antibody (basiliximab) for immunosuppressive induction therapy after liver transplantation: a protocol with early elimination of steroids and reduction of tacrolimus dosage. Liver Transpl 2004;10:728-733

9. Arroyo V, Gines P, Gerbes AL, Dudley FJ, Gentilini P, Laffi G, et al. Definition and diagnostic criteria of refractory ascites and hepatorenal syndrome in cirrhosis. International Ascites Club. Hepatology 1996;23:164-176 
10. Kamath PS, Wiesner RH, Malinchoc M, Kremers W, Therneau TM, Kosberg CL, et al. A model to predict survival in patients with end-stage liver disease. Hepatology 2001;33:464-470

11. Goldstein MJ, Salame E, Kapur S, Kinkhabwala M, LaPointeRudow D, Harren NPP, et al. Analysis of failure in living donor liver transplantation: differential outcomes in children and adults. World J Surg 2003;27:356-364

12. Marcos A, Ham JM, Fisher RA, Olzinski AT, Posner MP. Singlecenter analysis of the first 40 adult-to-adult living donor liver transplants using the right lobe. Liver Transpl 2000;6:296-301

13. Icoz G, Kilic M, Zeytunlu M, Celebi A, Ersoz G, Killi R, et al. Biliary reconstructions and complications encountered in 50 consecutive right-lobe living donor liver transplantations. Liver Transpl 2003;9:575-580

14. Rajekar H, Wai CT, Majeed TA, Lee KH, Wong SY, Leong SO, et al. Prognostic factors in patients with acute liver failure undergoing live donor liver transplantation. Transplant Proc 2008;40(8):2492-2493

15. Fan ST, Lo CM, Liu CL, Wang WX, Wong J. Safety and necessity of including the middle hepatic vein in the right lobe graft in adult-to-adult live donor liver transplantation. Ann Surg 2003;238:137-148

16. Heemann U, Treichel U, Loock J, Philipp T, Gerken G, Malago $\mathrm{M}$, et al. Albumin dialysis in cirrhosis with superimposed acute liver injury: a prospective, controlled study. Hepatology 2002;36: 949-958

17. Yuen MF, Sablon E, Hui CK, Li TM, Yuan HJ, Wong DK, et al. Prognostic factors in severe exacerbation of chronic hepatitis B. Clin Infect Dis 2003;36:979-984 